\title{
A Legal Approach to Winning the 'Wash' War in Nigeria
}

\author{
Opeyemi Adewale Gbadegesin ${ }^{1 *}$, Simisola O. Akintola ${ }^{1}$
}

${ }^{1}$ Faculty of Law, University of Ibadan, NIGERIA

*Corresponding Author: opeyemigbadegesin84@gmail.com

Citation: Gbadegesin, O. A. and Akintola, S. O. (2020). A Legal Approach to Winning the 'Wash' War in Nigeria. European Journal of Environment and Public Health, 4(2), em0043. https://doi.org/10.29333/ejeph/8237

ARTICLE INFO

Received: 20 Apr. 2020

Accepted: 24 Apr. 2020

\begin{abstract}
Open defecation has continued to pose serious health and environmental challenges globally. This practice affects almost 1 billion people worldwide and is said to contribute significantly to an estimated 842,000 deaths resulting from sanitation related diseases. A survey conducted by UNICEF ranks Nigeria as the African country with the highest population practicing open defecation and the second next to India globally. To tackle this and to prevent an environmental and health crisis, a state of emergency was declared in the water supply, sanitation and hygiene services (WASH) sector that led to the signing of an executive order to end open defecation by 2025. The objective is to eliminate open defecation and also ensure that SDG 6 is achieved especially in the rural areas. This paper posits that achieving an open defecation free status has and still remains a primary target for the government in Nigeria at all levels and the machinery of law be deployed as a viable tool to achieve this target. It submits that for this target to be met, there is the need to recognize the right to sanitation as one of the key ways to address sanitation issues especially open defecation. Articulating this right in a way that respects equity, human rights and environmental sustainability will effectively aid in the realization of the goal of ending open defecation by 2025 .
\end{abstract}

Keywords: open defecation, sanitation, legislation, Nigeria

\section{INTRODUCTION}

Good hygiene practice is an important aspect of environmental public health as a result of its impact in disease prevention and control, especially as it concerns waterborne and sanitation related diseases. Open defecation can be described as an unhygienic human practice of defecating outside rather than in a toilet. The alternatives to using a toilet usually considered include fields, bushes, forests, ditches, streets canals or other open spaces (Clansen et al., 2014). This practice is predominant in areas where sanitation and toilet infrastructures and services are not readily available. In a water sanitation and hygiene (WASH) survey conducted by the Nigerian Ministry of Water Resources and National Bureau of Statistics with support from United Nations Children's Fund (UNICEF), it was discovered that one of the impediments to proper hygiene in Nigeria is the high prevalence of open defecation. (UNICEF, 2018). The result from this survey placed Nigeria as the African country with the highest population practicing open defecation and the second globally next to India. According to the results only 11 percent of the population, 7 percent of schools and 5 percent of health facilities have access to basic WASH facilities. This report showed the severity of the problem of open defecation for Nigeria and the health and environmental challenges it poses for the citizens especially the poor. In 2016 an action plan to end open defecation by 2025 was launched by the Nigerian government spearheaded by the Federal Ministry of Water Resources. By 2018 it was discovered that many parts of the country struggled with high levels of water borne diseases traceable to poor sanitation practices especially open defecation (Okpasuo et al, 2018).This led to a declaration of a state of emergency in the water, sanitation, and hygiene sector (Guardian, 2018). To further show its commitment to ending the practice of open defecation and in compliance with the SDGs for Water (Goal 6.1) and Sanitation (Goal 6.2) a Presidential Executive order 009 titled " The Open defecation free Nigeria by 2025 and other related matters Order" was signed in 2019 (Punch, 2019). The order reflects the determination of the government to create an enabling environment to support the elimination of the practice of open defecation and improve the sanitation and hygiene practices in Nigeria within a five-year period. The order though an administrative one provides that the National Assembly and the State Houses of Assemble shall enact legislation on the practice of open defecation with appropriate sanctions and penalties. This is necessary because effectively combating the scourge of open defecation in Nigeria would improve the quality of life and the environment as well as aid in the actualization of fundamental rights particularly the rights to 
life and human dignity as contained in section 33 and 34 of the Constitution (Obani et al., 2014).

Ending open defecation would go a long way in improving the sanitation level in Nigeria and this can best be achieved through the recognition of the right to sanitation. To effectively put this argument in perspective, the paper would in the first section review literature on open defecation in Nigeria to establish its casual relations to health and environment. The second section reviews and analyses existing laws and policies to provide guidance on the extant laws and the role of law as an intervention in ending this practice. The paper also offers some commentary on the police powers of the state to mandate compliance in the exercise of its duties to protect and promote the health and environment of its citizenry. The third sections argue for the recognition of the right to sanitation as one of the ways to ensure effective implementation of laws enacted to address sanitation issues in Nigeria. Articulating this right is necessary to fulfill the goal of ensuring human dignity of every Nigerian as the government seeks to effectively end the practice of open defecation and improve the general level of sanitation hygiene practices in Nigeria. The paper would conclude by recommending that the recognition of right to sanitation as a human right should be the focus of environmental sanitation laws at all levels of government to ensure that the aim of making Nigeria open defecation free by 2025 is achieved.

\section{LITERATURE REVIEW}

\section{Open Defecation in Nigeria}

With a population of about 186 million (around half living in urban areas), Nigeria is the most populous nation in Africa and seventh in the world, and the population is estimated to reach about 400 million in 2050 to become the third largest nation on earth after India and China (World Bank, 2016). As a result of this large number, Nigeria is ranked among the nations in the world with the highest number of people who engage in the practice of open defecation, with an estimated of over 46 million people in rural and urban areas engaging in this act (UNICEF, 2017). This figure is significant given the role Nigeria plays as one of the most developed countries in the West African region and Africa as a whole.

The prevalence of this practice according to UNICEF Fact Sheet (UNICEF, 2010) is linked to the over 12 million Nigerians that have no access to safe water and about another 40 million who are without improved sanitation. The 2018 National Demographic and Health Survey (NDHS) reports 56\% of Nigerian households use improved toilet facilities, $74 \%$ of whom are in urban areas and 39\% in rural areas. Going by this report, the proportion of households with no toilet facility has decreased over the last 5 years, from $29 \%$ of households in 2013 to $25 \%$ of households in 2018 . However, open defecation remains widespread in Nigeria, with $25 \%$ of households (33\% of rural households and $15 \%$ of urban households) engaging in this practice.

Unhealthy and unhygienic cultural practices contribute to the prevalence of the practice of open defecation in rural communities in Nigeria. Culture, values, tradition and morals of the people determine how well they assimilate and imbibe "new" ways of sanitation. In some rural communities in Nigeria, people delight in defecating openly in rivers and lakes which also serves as a source for drinking water, thereby denying self of safe and clean water as well as sanitary environment (Ngwu, 2017). Most of the people practicing this act have grown up seeing family members, peers, and others in the community defecate in the open and as such see this practice as habitual, natural and part of a daily routine. Norms and Practices held from childhood tend to stick and become a way of life such that even where the facilities are available, the practice of open defecation remains the preferred option (Connell, 2014).

The growth of this practice is also attributed to the everincreasing population and the absence of sanitation facilities in most homes in the cities thus resulting in the people finding alternatives to answer the call of nature. There is also relationship between wealth/social status of the individual and open defecation. Improved sanitation owners are usually wealthier than those who engage in open defecation. High income earners because of their social status are more concerned about hygienic ways of disposal of waste as compared to low income earners. Osumanu et al 2013 while studying the economic factors that encourage open defecation explained that financial constraints poses two challenges to ending open defecation. Low income earners who are house owners because of financial constraint did not provide household toilets facilities within their premises, and secondly, where these facilities are not available at home and public toilets are provided, inability to afford fees charged by public toilet operators could drive them towards defecating in the open. The implication of this is that where a household cannot afford to construct toilet facilities and individuals cannot afford the fees for the use of a public toilet, it only leaves one alternative, open defecation.

In Uttarakhand, India, O'Reilly et al. (2017) found that remoteness (being away from built up areas), access to water, subsidies, and race and income inequalities influences the prevalence of Open Defecation in the study area. In Java, Indonesia Mukherjee et al. (2012) found that proximity to water bodies and vegetation, behavior change communication, and community-provided subsidies significantly influence Open Defecation. The case of Nigeria is not different as Abubakar (2018) argues that the regional variation in Nigeria, differences in vegetation, topography and water bodies presents a possible explanation for higher incidence of open defecation in the South West and Central regions due to their proximity to forests which offers more opportunity and cover for the practice, unlike in the North where the savannah vegetation could discourage the practice.

In Nigeria, households in which the heads are educated beyond secondary education were the least to practice open defecation (Abubakar, 2018). This is attributed to the fact that the more-educated households are more informed regarding health and environmental threats of open defecation. To add credence to the above, WHO in its 2015 survey found that the proportion of the population practicing open defecation seems to decline with increasing levels of education (UNICEF/WHO, 2015). 
The practice of open defecation has had huge environmental and health implications for all citizens in Nigeria. The effect is not only limited to those in the rural areas or those practicing it in the urban areas but poses a great challenge for all and sundry. Diseases such as diarrhea, typhoid, and cholera amongst other infectious diseases are prevalent in areas where the inappropriate disposal of human waste takes place. Orilomoloye (2015) explained that agents of disease or pathogens such as bacteria, viruses, parasites etc. which are passed out in feces if not properly disposed of contaminates the sources of drinking water supply. He argues that it has been scientifically established that one gram of feces may contain as many as 10,000,000 viruses, 1,000,000 bacteria, 1,000 parasite cysts and 100 worm eggs (Rose et al., 2015). The effect is an increase in the cases of water borne diseases and a rise in other associated infectious diseases. Closely related to the health problem is the impact of this practice on women and girls because of the need for privacy during sanitary activities. Where facilities are not available and the only option is open defecation, the girls may need to walk long distances to fetch water and to defecate and may result in exposure to violence (Egbinola et al., 2015).

Apart from the health effects of open defecation, the environmental challenges its poses in terms of polluting water ways is also a course for concern. Open defecation not only deteriorates the quality of drinking water but also makes the water unfit for drinking purposes (Tambekar et al., 2012). Open defecation has also resulted in conversion of large areas of land within the community into fecal fields. These 'fecal fields' potentially put the environment and consequently water sources at risk of flooding with fecal material from surrounding areas during rains (Luby et al., 2008).

Open defecation also results in the contamination of local environment with human feces, including surface water, public spaces, roadsides and railway lines, and it pollutes the air with foul odor. It also manifests through the use of flying toilets which are human excreta wrapped and indiscriminately thrown away. For example, open defecation pollutes beaches in Lagos and other Nigerian coastal cities thereby decreasing their potentials to attract local and international tourists (Abubakar and Dano, 2018). Economically open defecation reduces the human capital of a country's workforce and inhibits people's physical and cognitive development (Mara, 2017). Care givers and parents have to bear the task of taking care of the sick children thereby loosing hours of labor productivity time and also income and long hours and finances are devoted towards taking care of the sick.

\section{LEGAL AND INSTITUITIONAL FRAMEWORK ON ENVIRONMENTAL SANITATION IN NIGERIA}

The Federal and state governments have been implementing a number of laws and policies to address sanitation issues. The impact on the environment and health coupled with the economic impact of poor sanitation practices necessitated the need to address the issue of sanitation using the instrument of the law. The Constitution of the Federal Republic of Nigeria 1999 provides in Section 20 that "The State shall protect and improve the environment and safeguard the water, air and land, forest and wildlife of Nigeria." This section represents an aspirational objective of state policy not a justiciable right under the constitution. ${ }^{1}$ The main objective of Section 20 of the 1999 Constitution as explained by the Supreme Court's in Attorney General of Lagos State and Attorney General of the Federation and 35 others is to protect the external surroundings of the people and ensure that they live in a safe and secure atmosphere free from any danger to their health or other conveniences. Though not expressly stated in the wording of the constitution, the idea of ensuring good sanitary practices can be deduced from the use of the word "safeguard" in Section 20. The supreme court in its wisdom goes on to elucidate further by criticizing the provision on the grounds that it merely places a mandatory duty on the State to direct its policies towards achieving the above environmental objective without placing any corresponding legal right on the citizens to enforce such provision or any other provisions of the Chapter in the event of non-compliance by the State. It is submitted that although the constitution places a duty on state to protect the environment, there is no deliberate, well thought out and comprehensive allocation of legislative competence on the environment. This calls for an urgent review of the constitutional allocation of responsibilities, legislation and institutional arrangements as it relates to environmental protection.

Government policies represent a statement of government intentions, strategies and overall vision for a given sector (Elledge et al., 2002). One of such policies in Nigeria on sanitation is the National Policy Water-Sanitation 2000 (Cookey, 2012) with the objective of ensuring that all Nigerians have access to adequate, affordable and sustainable sanitation services through the active participation of Federal, State and Local Governments, NGOs, Development Partners, Private sector, communities, households and individuals. The policy requires all tiers of government to release a vote for water sanitation of an amount equivalent to not less than $15 \%$ of their annual appropriation for water supply and sanitation programs. The objective of the policy though laudable failed to address the need to define the institutional roles of relevant Government Agencies involved with sanitation at the three tiers of Government, the Private Sector, NGOs and Development Partners. The policy also did not take into

\footnotetext{
${ }^{1}$ It is also worthy of note that there are no provisions for sanitation and/or waste management on the exclusive legislative list and the concurrent legislative list as contained in the constitution. The only mention of the subject matter is in the Fourth Schedule (Functions of a Local Government), where it says in $1(\mathrm{~h})$ that the main functions of a local government council are the provision and maintenance of public conveniences, sewage and refuse disposal.
} 
Table 1. Legal Intervention on Sanitation Issues in Nigeria

\begin{tabular}{|c|c|c|}
\hline LEGISLATION & Purpose for Enacting the Law & EFFECT OF THE LAW ON SANITATION (Open Defecation) \\
\hline $\begin{array}{l}\text { Harmful Waste (Special } \\
\text { Criminal Provisions) Act }\end{array}$ & $\begin{array}{l}\text { The Act Prohibits the carrying, } \\
\text { dumping of harmful waste on land, } \\
\text { territorial waters and matters relating } \\
\text { thereto. }\end{array}$ & $\begin{array}{l}\text { Although the word sanitation/ open defecation is not used in the Act, } \\
\text { the Act defines a harmful substance as any injurious,poisonous,toxic or } \\
\text { noxious substance that can subject a person to risk of death,fatal injury } \\
\text { or incurable impairment of physical or mental health. }\end{array}$ \\
\hline $\begin{array}{l}\text { Federal Environmental } \\
\text { Protection Agency Act }\end{array}$ & $\begin{array}{l}\text { The Act established the Federal } \\
\text { Environmental Agency saddled with } \\
\text { the responsibility of environmental } \\
\text { protection and development }\end{array}$ & $\begin{array}{l}\text { The Act makes no mention of sanitation but provides that the Agency } \\
\text { shall make recommendations to the President for the purpose of } \\
\text { establishing water quality standards for the inter-State waters of Nigeria } \\
\text { to protect the public health or welfare and enhance the quality of water } \\
\text { to serve the purposes of this Ac }\end{array}$ \\
\hline $\begin{array}{l}\text { Environmental Impact } \\
\text { Assessment Act }\end{array}$ & $\begin{array}{l}\text { The act sets out the general principle, } \\
\text { procedure, methods to enable the } \\
\text { prior consideration of Environmental } \\
\text { impact assessment on certain public or } \\
\text { private projects }\end{array}$ & $\begin{array}{l}\text { The Act designed for environmental protection also fails to include the } \\
\text { subject of sanitation. The Agency has as part of its responsibility to } \\
\text { approve or disapprove project that have a negative impact on the } \\
\text { environment }\end{array}$ \\
\hline $\begin{array}{l}\text { National Policy on The } \\
\text { Environment }\end{array}$ & $\begin{array}{l}\text { The policy document represents the } \\
\text { intention of the government on the } \\
\text { sustainable use of the environment }\end{array}$ & $\begin{array}{l}\text { The policy does not have sanitation as its primary focus but recognizes } \\
\text { the importance of water and the need to safe guard it from } \\
\text { contamination in its natural form. Open defecation usually takes place } \\
\text { along water ways thus water needs to be safeguarded from } \\
\text { contamination that may lead to water pollution and this is strongly } \\
\text { supported in the document. }\end{array}$ \\
\hline $\begin{array}{l}\text { Lagos State Environmental } \\
\text { Sanitation law }\end{array}$ & $\begin{array}{l}\text { The law was enacted to provide for } \\
\text { environmental sanitation in Lagos } \\
\text { State and to establish environmental } \\
\text { sanitation corps }\end{array}$ & $\begin{array}{l}\text { The law states that no person shall cause or knowingly permit any trade } \\
\text { or sewage affluent or liquid waste to be discharged into any drain or } \\
\text { drainage system expect at authorized place. It also imposes a fine of } \\
\text { N5000 on any person caught discharging sewage into a public place. }\end{array}$ \\
\hline $\begin{array}{l}\text { Bayelsa State Environmental } \\
\text { Sanitation Authority Law }\end{array}$ & $\begin{array}{l}\text { The law established the Bayelsa State } \\
\text { Environmental sanitation Authority }\end{array}$ & $\begin{array}{l}\text { The Authority is responsible for the management of solid waste disposal } \\
\text { in the state. }\end{array}$ \\
\hline $\begin{array}{l}\text { Borno State Rural Water and } \\
\text { Sanitation Agency Law }\end{array}$ & $\begin{array}{l}\text { The law established the Borno state } \\
\text { rural water supply and sanitation } \\
\text { Agency }\end{array}$ & $\begin{array}{l}\text { The law recognizes the relationship between water and sanitation and } \\
\text { tasks the agency to ensure sustainable access to safe water supply, } \\
\text { sanitation and hygiene services to the rural communities in Borno State. }\end{array}$ \\
\hline
\end{tabular}

Source: Laws of the Federation, 2004, Laws of Lagos, Bayelsa and Borno States

cognizance the roles and responsibilities of communities and individuals as well as the importance of hygiene education neither did it provide for a corresponding legal right for the citizens to demand compliance.

Further down the line in 2005, the National Environmental Sanitation Policy was designed to serve as an instrument for securing quality environment for good health and social wellbeing of present and future generations. The Policy defined environmental sanitation as the principles and practice of effecting healthful and hygienic conditions in the environment to promote public health and welfare, improve quality of life and ensure a sustainable environment. The policy recognized that a pleasant environment that is hazard free and promotes healthful living, is a fundamental right of all Nigerians. The key points that emerged from this policy document are: there is currently no existing law to give effect to the constitutionally guaranteed right to a clean and healthy environment. The Federal Ministry of Environment and the various State Ministries of Environment and Water Resources are responsible for ensuring hygiene and sanitation. This position conflicts with that of the Nigerian Constitution which makes it the responsibility of the local governments. Given the prevalence of open defecation from the survey conducted by UNICEF, it would seem that the policy has failed in its objective to provide a healthy environment. This policy gave birth to other ancillary policy guidelines on major thematic issues on Environmental Sanitation. Of primary importance to the subject of sanitation and open defecation are; the Policy Guidelines on Solid Waste Management which aims to improve and safeguard public health and welfare through efficient sanitary Solid Waste Management methods that will be economical, sustainable and guarantee sound environmental quality, The Policy Guideline on School Sanitation which aimed at provide an optimal sanitary environment which is safe and conducive for physical, mental and emotional health of the school community in order for the child to achieve benefits from educational programs, The Policy Guidelines on Excreta and Sewage Management with the aim of ensuring countrywide access to efficient and sustainable excreta and sewage management methods and obviate associated public health hazards. While all these policy guidelines reflect the government's intention and aspiration to improve the sanitary practices, there exists the problem of implementation. The alarming at which heaps of solid wastes occupy most Nigerian cities, coupled with the fact that $87 \%$ of Nigerians use methods adjudged as insanitary, the breeding of rodents, mosquitoes and other pests gives credence to the lapses in the implementation of the objectives of these policies. Ineffective sensitization and public enlightenment strategies are reflected in the public's inability to adopt environment friendly habits and practices. Insufficient infrastructure for schools and homes hinders the propagation of hygienic practices. Sanitary facilities for schools are insufficient where they exist and are virtually absent in other schools (Egbinola et al 2015). Studies show that a sizeable portion of the population are unaware of existing legislation on solid waste management (Olowoporoku, 2017). The aspirations and objectives of these policies if properly implemented were to create awareness on the effects of insanitary excreta and sewage management on the quality of the environment and public health. The fact that 
open defecation is still been practiced with impunity suggests that much still needs to be done.

National Environmental Standards and Regulations Enforcement Agency (NESREA) was established in 2007 to be responsible for the protection and development of the environment, biodiversity conservation and sustainable development of Nigeria's natural resources in general and environmental technology including coordination, and liaison with, relevant stakeholders within and outside Nigeria on matters of enforcement of environmental standards, regulations, rules, laws, policies and guidelines. In relation to environmental sanitation, the agency is empowered to make regulations for the purpose of protecting public health and promotion of sound environmental sanitation. NESREA in the exercise of its powers is expected to collaborate with the State Environmental Protection Agencies and other bodies whose functions relate to the environment. This would be especially necessary in a situation where there is an overlapping of functions or roles between the Federal, State and Local Governments. In 2009 the exercise of its powers under NESREA Act, the Minister of Environment came up with several regulations for the general purposes of carrying out or giving full effect to the functions of the Agency. In relation to sanitation, National Environmental (Sanitation and Wastes Control) Regulations, applies to issues in environmental sanitation, particularly food, market and industrial sanitation; and all categories of wastes generated therein, especially, community, end-of-life, hazardous, health care, industrial, radioactive, leaf and yard, solid and packaging wastes. It further deals with environmental sanitation matters relating to general cleanliness, duties of owners and occupants of properties and premises, citizens' obligations, extended producer's responsibility, the polluter pays principle and banned pesticides or chemicals for domestic fumigation. The regulation also provides for detailed provisions on the control of solid waste, effluent discharge, and hazardous and health care wastes.

The existing institutional framework on open defecation in Nigeria include the establishment of the National Task Group on Sanitation (NTGS) at federal level, as well as Rural Water Supply and Sanitation Agencies (RUWASSA), State Task Group on Sanitation (STGS), and WASH departments and committees (WASHCOMs) at state and local government area (LGA) levels. In 2004 a pilot community led total sanitation (CLTS) program was established to help communities recognize the adverse effects of poor sanitation, especially open defecation, and to assist them to develop a plan and act towards becoming totally open defecation free. This program was developed through a partnership between the government and UNICEF, Water Aid and other NGOs, The CLTS program involved construction of public toilets, provision of subsidized toilet slabs, WASH program in schools, and public hygiene education. In 2007 the program was adopted nationwide and by the end of 2014, it had been implemented in about 20000 communities in 301 LGAs (IDS, 2015). A guideline for certifying communities as open defecation free was also developed, and the communities that claimed open defecation free status have risen from 509 in 2010 to 16766 in 2016, representing thirty-fold increase (Nadar, 2016). There has also been progress in certifying communities as open defecation free from $17 \%$ of the claims in
2012 to $25 \%$ in 2016 (Nadar, 2016). Albeit these efforts through the machinery of laws and policies, open defecation prevalence in Nigerian has continued to increase. The focus of this paper is to advocate for a comprehensive legislation which addresses sanitation in general and the right to sanitation in particular as a new approach to addressing the practice of open defecation.

\section{A NEW APPROACH TO WINNING THE WAR; THE RIGHT TO SANITATION}

Despite this focus and increasing budget allocations, the abysmal sanitation scenario on the subject of open defecation in the country persists. The Executive order signed by the president recognizes the need for both national and state legislative arms to make laws backed up with sanctions that will aid the government in achieving its aim of having an open defecation free Nigeria by 2025 . Although the political will exists to make Nigeria open-defecation free at national level, there is not much of its evidence on ground to show that any of the efforts have yielded any meaningful results.

The Legal Framework that currently exists on open defecation in Nigeria relates to enforcement of certain provisions of environment protection law only. There is therefore the need for advocacy at the legislative level to recognize the right to sanitation as part of the agenda in making the efforts of the executive yield the desired results. Access to sanitation needs to recognized as a human right issue and the government in the exercise of its compulsory powers to promote and protect the health of its population needs to place importance on the right to sanitation to effectively aid the government in the realization of its goal of ending open defecation by 2025 .

Section 33 and 34 of the Constitution of the Federal Republic of Nigeria, provides for the right to life and the right to dignity of person. The practice of open defecation affects the full realization of these rights owing to the negative environmental and health effects this practice has on citizens. With a rise in the practice, the health and wellbeing of the populace is challenged (right to life) and where sanitation facilities are not provided, the populace are forced to engage in undignified methods of defecation (right to human dignity). Open defecation adversely affects the life of the citizen and it amounts to slow poisoning and reducing the life of the citizen because of the hazards created, if not checked.

The importance of giving recognition to the right is linked to the fact that addressing the problems it causes will have positive consequences for a number of other fields, ranging from water quality, public health and the environment in general. Water and sanitation have been linked for decades. Most sewage find its way into watercourses or the environment without treatment the consequence of which is that most communicable diseases are water related (Okullo et al., 2017).

The courts in several cases have consistently advocated that for the right to life and human dignity to be given full effect, the right to clean and healthy environment is essential. In Virendra Gaurv State of Haryana, the Supreme Court of India while debating Haryana's Town Planning Scheme in a case 
concerning the Municipal Committee of Thanesar's proposed land-use change for an area earmarked for open spaces, asserted that the 'right to life with human dignity' encompasses sanitation with pollution-free water and air and the broader protection of the environment. In the Nigerian case of Gbemre $V$ Shell Petroleum Development Company of Nigeria Limited and Others, the court held that the practice of gas flaring is unconstitutional as it violates the guaranteed fundamental rights of life and dignity of human persons as provided for the Constitution of the Federal Republic of Nigerian and the African Charter on Human and Peoples Rights. In Kenya, the High Court in Mwaniki and ors V Gicheha and ors held that the right to clean and healthy environment is fundamental right of citizens and any act that is likely to contravene this right must be checked.

It goes without saying therefore that the practice of Open defecation because of its negative consequences is an affront on the fundamental rights of humans and the way to challenge this practice is through the recognition of the right to sanitation as a derivative of the right to life and human dignity. The right to sanitation will only become a reality when there is a direct reference to it within a legal framework that would allow for its full realization. From this point of view there arises the need for the legislature to impose a duty on the government to plan for rural sanitation and assign certain sanitation duties to its agencies. The realization of the right will impose a duty on the government to ensure the maintenance of general sanitation, cleaning up of drains, the construction and maintenance of public latrines, as well as the management and washing of these public latrines.

The right to sanitation has been recognize and affirmed in various international treaties and political commitments. It is recognized as a fundamental human right that is necessary if the goal of ensuring human dignity of each individual is to be fulfilled. Article 14(2) (h) of The Convention on Elimination of Discrimination against Women, 1979 provides that: State parties shall ensure to women: ...the right to enjoy adequate living conditions, particularly in relation to ... sanitation.... Article 24 of the Convention on the Rights of the Child, 1989, in recognizing the right of the child provides that States parties shall pursue full implementation of this right and, in particular, shall take appropriate measures: To ensure that all segments of society, in particular parents and children, are informed, have access to education and are supported in the use of basic knowledge of child health and nutrition, the advantages of breastfeeding, hygiene and environmental sanitation, and the prevention of accidents. The legal basis of the right to water is premised on the fact that the human right to water entitles everyone to sufficient, safe, acceptable, physically accessible and affordable water for personal and domestic uses. An adequate amount of safe water is necessary to prevent death from dehydration, to reduce the risk of waterrelated disease and to provide for consumption, cooking, personal and domestic hygienic requirements. (The Right to Water, 2012). The UN General Assembly Resolution, 2010 recognizes the right to sanitation and acknowledges "the importance of equitable, safe and clean drinking water and sanitation as an integral component of the realization of all human rights.”
Haven established that sanitation is fundamental for human survival and for leading a life in dignity, the right to sanitation as a component of the legal framework that would serve as a panacea and complement the political will of the government in Nigeria to end open defecation is justified on the following grounds;

(a) Explicit legal recognition of the right to sanitation will make it a legal entitlement, rather than a charity or only a moral priority.

(b) A legal entitlement provides opportunities for the right holders to make duty bearers accountable.

(c) Concerns and interests of vulnerable and marginalized groups will get priority attention.

This would provide an opportunity for governments, civil society and other stakeholders to pay particular attention to defining specific standards for the right to sanitation and subsequently for the realization of this right. In the realization of this rights the laws to be promulgated both at the federal, state and local government levels will provide a system for the collection, transport, treatment and disposal or re-use of human excreta and associated hygiene. It would also seek to ensure that everyone, without discrimination, has physical and affordable access to sanitation, in all spheres of life, which is safe, hygienic, secure, socially and culturally acceptable, provides privacy and ensures dignity. As a tool for correcting deviant behavior, the law will seek to impose sanctions for failure to comply with government directive on the use of sanitation facilities and the disposal of human excreta.

The legal framework for articulating the right to sanitation in Nigeria will include the following elements.

(a) Ensuring that sanitation needs and concerns of vulnerable and marginalized sections of the society on a priority basis.

(b) Ensuring that the facilities and infrastructure created are in accordance with geographical and environmental conditions, even as they are sensitive to the specific needs of different sections of the society and their life cycles, which would specifically include ensuring of designs that are inclusive for women and men, the old and young, and those with varying forms of disability, even as it ensures the availability of water for personal hygiene and menstrual hygiene management;

(c) Ensuring that no human being is manually involved in cleaning human excreta.

(d) Ensuring health and environmental safety;

(e) Ensuring safety and dignity of sanitation workers;

(f) Ensuring the availability of sanitation facilities in public places;

(g) Ensuring appropriate infrastructure and resources so that all human beings at all times have access to sanitation facilities.

In addition, for the right to sanitation to be recognized, the framework must have in place a system whereby the right holders can approach the state to remedy the violation of their right. Thus, the establishment of competent institutions through which individuals can claim their right is a must. The state being the primary duty bearer in the context of the right 
to sanitation, there must exist a mechanism to ensure accountability of the duty bearer.

\section{RECOMMENDATIONS AND CONCLUSION}

The goal of ending open defecation is an important step in the realization of the right to sanitation. Building toilets for all may only be short term solution if the right to sanitation is not recognized through a legal framework directed as it. There arises the need for a behavioral change which can be affected through sanctions and punishments which on the instrument of law can provided. Effectively winning the WASH war involves having the law as a potent weapon in the arsenal of the government to ensure that political will is given full effect. The emphasis on access to sanitation and the full realization of the right to sanitation will ensure that when initiatives are developed, they come to full realization because they would match up to the ideals of the right to sanitation. Where administrative directions and legal frameworks are not well synchronized, the impact of sanitation interventions on the realization of other rights may not be felt. For instance, the success of the campaign in terms of toilet construction may not extend to overall success in terms of a broader reading when access to sanitation and right to sanitation is not backed up by a legal framework. By implication, places that have been declared open defecation free but whose infrastructure have deteriorated would go back to open defecation because the shift in behavior is yet to be completed.

\section{REFERENCES}

Abubakar, I. R. (2018). Exploring the determinants of open defecation in Nigeria using demographic and health survey data. Science of the Total Environment: 637-638C(2018), 1455-1465.https://doi.org/10.1016/j.scitotenv.2018.05.104

Abubakar, I. R. and Dano U. L. (2018). Socioeconomic challenges and opportunities of urbanization in Nigeria. In Urbanization and Its Impact on Socio-Economic Growth in Developing Regions, 219-240. https://doi.org/10.4018/9781-5225-2659-9.ch011

Aginam, O. (2001). "Public health law in South Africa by Sundrasagaran Nadasen” Indiana Journal of Global Legal Studies, $8(2), \quad$ Available at: http://www.repository.law.indiana.edu/ijgls/vol6/iss2/10

Akamabe, U. B. and Kpae, G. (2017). A critique on Nigeria national policy on environment: Reasons for policy review. IIARD International Journal of Geography and Environmental Management, 3(3), 22-36. Available at: www.iiardpub.org

Clansen, T., Boison, S., Routray, P., Torondel, B., Bell, M., Cumming, O.... and Schmidt, W. (2014). Effectiveness of a rural sanitation program on diarrhea, soil transmitted helminth infection, and child nutrition in Odisha, India: a cluster -randomized trial. (2014) The Lancet Global Health, 2(11), E645-E653. https://doi.org/10.1016/S2214-109X(14) 70307-9
Connell, K. O. (2014) What Influences Open Defecation and Latrine Ownership in Rural Households? Findings from a Global Review, World Bank, Washington, DC, USA.

Cookey, P. (2012). Developing sustainable policies, legislative and regulatory framework for sanitation and waste management in Nigeria. A Paper Presented at the Capacity Building Program for Parliamentary Support Staff of States and National Assembly; on the 18th April 2012 at the African Leadership Forum Conference Centre, Ota, Ogun State, Nigeria.

Cullet, P. (2016) Policy as law: Lessons from sanitation interventions in rural India. Stanford Journal of International Law, 54, 241-258.

Duncan, J. C. (2010). A critical consideration of executive orders: Glimmerings of autopoiesis in the executive role. Vermont law Review, 35(333), 333-411.

Egbinola, C. N. and Amanambu, A. C. (2015). Water supply, sanitation and hygiene education in secondary schools in Ibadan, Nigeria. In: Szymańska, D. and Środa-Murawska, S. editors, Bulletin of Geography. Socio-economic Series, No. 29, Torun: Nicolaus Copernicus University, 31-46. https://doi.org/10.1515/bog-2015-0023

Elledge, M. F., Rosensweig, F., Warner, D. B., Austin, J. and Perez, E. A. (2002). Guidelines for the assessment of national sanitation policies. Strategic Report 2. Prepared for the Office of Health, Infectious Diseases and Nutrition, Bureau for Global Health, U.S Agency for International Development, under EHP Project 26568/CESH.SANITATION. POLTOOL.

Guardian. (2018). FG declares state of emergency in water, sanitation sector (Joke Falaju), Guardian, 16 April, 2018. Available at: https://m.guardian.ng/property/fg-declaresstate-of-emergency-in-water-sanitatio-sector/ (Accessed: 27 March 2020).

Ijaiya, H. and Joseph, O. T. (2014). Rethinking environmental law enforcement in Nigeria. Beijing Law Review, 5, 306-321. https://doi.org/10.4236/blr.2014.54029

Kalu, R. E., Etim, K. D., Jonathan, O. A. and Eja, M. E. (2019). Open defecation profile of rural communities in Cross River and Akwa Ibom States of the Niger Delta, Nigeria. Int. J. Curr. Microbiol. App. Sci, 8(12), 2332-2340. https://doi.org/10.20546/ijcmas.2019.812.275

Koonan, S. (2016). Right to sanitation in India, nature and scope. In K.J. Joy and Sarita Bhagat (Eds), Right to Sanitation in India: Nature, Scope and Voices from the Margins (Pune: Forum for Policy Dialogue on Water Conflicts in India, (2016), 1-14.

Ladan, M. T. (2012) 'Review of NESREA Act 2007 and Regulations 2009-2011: A New Dawn in Environmental Compliance and Enforcement in Nigeria'. Law, Environment and Development Journal, 8(1), 116. https://doi.org/10.2139/ssrn.2335606

Luby, S. P., Gupta, S. K., Sheikh, M. A., Johnston, R. B., Ram, P. K. and Islam, M. S. (2008). Well water quality and predictors of contamination in three flood-prone areas in Bangladesh. Appl Microbiology, 105, 1002-1008. https://doi.org/10.1111/j.1365-2672.2008.03826.x 
Mara, D. (2017). The elimination of open defecation and its adverse health effects: a moral imperative for governments and development professionals. Journal of Water, Sanitation and Hygiene for Development, 7(1), 1-12. https://doi.org/10.2166/washdev.2017.027

Mitsunori, O., Zainal, M., Aidan, A. C., Michael, E. G., Aldy, K. M., Khaerul, U. and Yameha, T. A. (2017). Enabling factors for sustaining open defecation-free communities in rural Indonesia: A cross-sectional study. Int. J. Environ. Res. Public Health, 2017(14), 1572. https://doi.org/10.3390/ ijerph14121572

Mukherjee, N., Robiarto, A., Saputra, E. and Wartono, D. (2012). Achieving and sustaining open defecation free communities: learning from East Java. Report from WSP. Washington, DC: World Bank.

Nadar, K. (2016). Can Nigeria achieve ODF with Business as Usual? Presented at the National CLTS Conference and Launch of ODF Roadmap from Nigeria, 22nd November 2016. Available at: http://www.communityledtotalsanita tion.org/sites/communityledtotalsanitation.org/files/Can Nigeria_achieve_ODF_with_business_as_usual.pdf (Accessed: 24 March 2020).

Ngwu, U. I. (2017). The practice of open defecation in rural communities in Nigeria: A Call for Social and Behavior Change Communication Intervention. International Journal of Communication Research, 7(3), 201-206.

Obani, P. and Gupta, J. (2015). The Evolution of the right to water and sanitation: differentiating the implications. Review of European, Comparative and International Environmental Law, 24(1), 27-39. https://doi.org/10.1111/ reel.12095

Oguntoke, O., Aboderin, O. J. and Bankole, A. M. (2009). Association of water-borne diseases morbidity pattern and water quality in parts of Ibadan city. Nigeria. J. Health Res., 11(4), 189-195. https://doi.org/10.4314/thrb.v11i4.50174

Okpasuo, J., Okafor, F. C. and Aguzie, I. (2018). Effects of household drinking water choices, knowledge, practices and spatio-temporal trend on the prevalence of waterborne diseases in Enugu Urban Nigeria. International Journal of Infectious Diseases, 73(Supplement), 225. https://doi.org/10.1016/j.ijid.2018.04.3926

Okullo, J. O., Moturi, W. N. and Ogendi, G. M. (2017). Open defecation and its effects on the bacteriological quality of drinking water sources in Isiolo County, Kenya. Environmental Health Insights, 11, 1-8. https://doi.org/ 10.1177/1178630217735539

Oloruntoba, E. O. and Sridhar, M. K. (2007). Bacteriological quality of drinking water from source to household in Ibadan, Nigeria. Afr. J. Med Sci., 36(2), 169-175.

Olowoporoku, O. A. (2017). A recipe for disaster: An assessment of environmental sanitation situation in Nigeria. MAYFEB Journal of Environmental Science, 1(2017), 1-5.

O’Reilly, K., Dhanju, R. and Goel, A. (2017). Exploring "the remote" and "the rural": open defecation and latrine use in Uttarakhand, India. World Development, 93, 193-205. https://doi.org/10.1016/j.worlddev.2016.12.022
Orimoloye, E. O., Amadi, C. O. A., Amadi, A. N., Azuamah, Y. C., Nwoke, E. A., Zacchaeus, U. and Dozie, I. N. S. (2015). Assessment of water sanitation and hygiene practices in Ibadan, Nigeria. International Journal of Research (IJR), 2(2), 94-100.

Osumanu, I. K. and Kosoe, E. A. (2013). Where do I answer nature's call? An assessment of accessibility and utilization of toilet facilities in WA, Ghana. Ghana Journal of Geography, 5(1), 17-31.

Punch. (2019). Buhari signs executive order 009 to end open defecation (John Ameh). Punch, 21 November, 2019. Available at: https://www.google.com/amp/s/punchng.com /buhari-signs-executive-order-009-to-end-open-defecati on/\%3famp=1 (Accessed: 27 March 2020).

Rose, C., Parker, A., Jefferson, B. and Carmel, E. (2015. The characterization of feces and urine: A review of literature to inform advanced treatment technology. Critical Reviews in Environmental Science and Technology, 45(17), 18271879. https://doi.org/10.1080/10643389.2014.1000761

Stanley, H. O., Orakwuemma, C. S., Onumajuru, B. O., Opukeme, A. S. and Onaghise, L. O. (2018). Assessment of solid waste disposal in Yenagoa, Bayelsa State, Nigeria. Asian Journal of Advanced Research and Reports, 1(4), 1-14, Article no. AJARR.43039. https://doi.org/10.9734/ajarr/ 2018/v1i413084

Tambekar, D. H. and Neware, B. B. (2012). Water quality index and multivariate analysis for groundwater quality assessment of villages of rural India. Sci Res Report, 3, 229235.

UNICEF. (2016). Making Nigeria Open Defecation Free By 2025: A National Road Map. Available at: https://www.unicef.org/nigeria/reports/making-nigeriaopen-defecation-free-2025-national-road-map

UNICEF. (2018). Water. Sanitation and Hygiene. Available at: https://www.unicef.org/nigeria/water-sanitation-andhygiene

UNICEF/WHO (2015). Progress on sanitation and drinking water - 2015 update and MDG assessment. Geneva: World Health Organization.

UNICEF/WHO (2017). Progress on drinking water, sanitation and hygiene: 2017 update and SDG baselines. Geneva: World Health Organization.

Winkler, I. T. (2016). The human right to sanitation. U. Pa. J. Int'l L, 37(4), 1333-1406.

World Bank (2016). World Development Indicators 2016: Featuring the Sustainable Development Goals. Databank. Washington DC: World Bank Group. https://doi.org/ 10.1596/978-1-4648-0683-4

World Bank. (2017). A Wake Up Call. Nigeria Water Supply, Sanitation, and Hygiene Poverty Diagnostic. Available at: www.worldbank.org (Accessed: 18 December 2019).

WSP (Water and Sanitation Program). (2012). Nigeria: Economic Impacts of Poor Sanitation in Africa. Available at: https://www.wsp.org/sites/wsp.org/files/publications/WSP -ESI-Nigeria-brochure.pdf (Accessed: 24 March 2020). 
Yilgwan, C. S., Yilgwan, G. and Abok, I. (2010). Domestic water sourcing and the risk of diarrhea: a cross-sectional survey of a peri-urban community in Jos, Nigeria. Niger J. Med, 19(3), 271-274. https://doi.org/10.4314/jim.v5i1.62024 